\title{
Stories, Curriculum Making, and Tension as Support for Identity Shifts: A Narrative Inquiry
}

Sandra Jack-Malik

\begin{abstract}
This research is nestled within Huber, Murphy, and Clandinin's (2011) understanding of curriculum making as situated not only in schools, but also in homes and communities and at the intersections of all three. It also relies on Clandinin, Murphy, Huber, and Orr's (2010) reconceptualization of tension as a space where educative experiences can occur. An autobiographical narrative inquiry into home, school, and community curriculum making, highlights an educator's efforts to teach relationally while being wide-awake to how past experiences inform future ones. This inquiry brings to life tension-filled moments and, in so doing, creates a space to know teachers as curriculum makers at home, at school, and in the community. It also suggests one of the values of autobiographical narrative inquiry is the safe space it creates to empathically enter the world of others. Mostly it encourages the reader to think about curriculum making as sentient, ever changing, and as an available support as teachers struggle to sustain their practices.
\end{abstract}

\section{In the Midst}

I sometimes wonder why particular stories linger and others do not. Is it because the stories compress and contain possibilities and profundity or is it that they offer continuous, moving links between who we were, are, and who we are struggling to become, our shifting identities? There are times when the lingering stories have wilful powers - much like a child who wants to play, but not with the toy offered. She sits on the side, not saying a word, yet screaming a sermon with her body language. My lingering stories are like that: demanding to be heard and taken up as shaping influences in the stories I tell, retell, live, and relive. ${ }^{1}$

A story from my first year of teaching lingers. I was working at a priority school ${ }^{2}$ in a large, urban city in central Canada. One day at a staff meeting, the principal introduced an article by Mclntosh (1989), White Privilege: Unpacking the Invisible Knapsack. The article speaks to unearned privileges people with white skin enjoy. The principal suggested children attending our school carried invisible knapsacks because they were living lives that often included hunger, poverty, parental underemployment, and so forth. Things that might not be seen, but things that were affecting children's learning. The connection was curious because it is not what McIntosh intended and most of the students were not white. He also said each staff member had one and suggested we empty our knapsack before entering school. 
Doing so would allow better focus on the complex needs of students. Very soon thereafter, my over full, invisible, knapsack slammed into my students, our community, and my family.

It was the morning following the Montreal Massacre, ${ }^{3}$ December 7, 1989. I had been teaching approximately three months. I was pregnant with my first child and utterly distraught knowing a gunman had targeted and murdered women. I rode my bike, in the cold, face into the wind with salty tears sopping my cheeks. I knew the contents of my invisible knapsack would enter the school and our classroom. I did my best to compose myself before opening the door.

The children entered and we went about the business of beginning our day and then settled upon the carpet for opening activities; part of this routine included children sharing news. Five-year-old

Alessandro, ${ }^{4}$ son of a political refugee from South America, put up his hand and slowly began telling our class (four- and five-year-olds) about the massacre. His Poppi, who had been a professor of political science, shared the story with him. Alessandro, in his perfect, commanding English, told the class how the man with the gun wanted to shoot girls and how Poppi said this was very bad. Sitting on a rocking chair, I listened and wept. The children's eyes were on me. I felt they wanted me to speak; I was incapable. Three girls—Shini from Sri Lanka and Hope and Jubilee, identical twins from Barbados—came to me. Shini put her head in my lap and reached her arms around me and my unborn child; the twins stood on either side of the rocker and draped their arms around my neck. I remember tiny, twig-like, twin arms stretching to reach in front and back of my head and then hook together. I let them soothe me; I let them remain. Alessandro looked and asked,

"Sandra, is it true?"

I replied,

"Yes."

As I cycled home, I reflected on our morning. I knew the children experienced me in unfamiliar ways. Many children had cried in our classroom; until that morning, I had not. In response, three girls physically reached out embracing and encircling me. I received their hugs and my emotional turmoil was temporally soothed. Thinking about the little girls, I also thought about the mothers in Montreal who would never again hug their daughters, and about the child growing within me. I wanted a way to thread together these three things: the children in my classroom, my unborn child, and the murdered women in Montreal; I was unsuccessful. ${ }^{5}$

I suspect my efforts to thread the stories were futile because I was experiencing them through disparate lenses: stories from school, stories from home, and stories from community. I needed a theoretical bridge to help me see them as interdependent relationships, constantly in motion, regardless of which landscape $^{6}$ they occurred on. This was difficult because at the time of my teacher training (1988-89), I was inducted into a profession that was compartmentalized. Students came to school to learn from teachers who delivered content. At the end of the day, teachers went home; there were no opportunities for paths to cross. As well, I learned that a well-organized classroom and detailed lesson, unit, and year plans kept tension at bay. I appreciated the idea of tension-free classrooms because I prefer to avoid conflict. Moreover, my principal's idea that teachers should arrive with an empty knapsack supported a 
view of curriculum as outcomes to be delivered by objective teachers. Finally, I grew up in a household where the word "love" was reserved exclusively for family members. A consideration of curriculum making outside of provincial documents and school, one that took in to account family, relationships, community, and love, precisely what the children shared with me on the day after the Montreal Massacre, was, at the time, unfathomable.

\section{Letting Go of Curriculum as Documents}

As a doctoral student, I took two courses with D.J. Clandinin: Curriculum Foundations and Inquiry in term one and Narrative Inquiry in term two of my first year of studies. Early in the first term, we each shared our definition of "curriculum." Dr. Clandinin then began a deliberate, layered, and intricate process of enculturation of other understandings of curriculum; I read broadly, I wrote, I discussed and slowly, I awakened to other views of curriculum. Views that allowed me to understand curriculum making in ways that were meaningful to my teaching practice and my life making. Similarly, I came to understand I could teach with a focus on the relational and the well-being of all.

I read Clandinin (1986) and Connelly and Clandinin's (1988) idea of personal practical knowledge and I grappled with it because I understood it meant letting go of provincial documents and Bloom's Taxonomy $^{7}$ while asking what I was doing with students and why. The authors described personal practical knowledge as "that body of convictions and meanings, conscious or unconscious, that have arisen from experience and that are expressed in a person's practices" (Clandinin and Connelly, 1995, p. 7). I was content to leave my body of convictions unexamined; I felt exposed by what the book asked of me. I also read Clandinin and Connelly's (1992) chapter where they suggested curriculum ".... be viewed as an account of teachers' and children's lives together in schools and classrooms" (p. 393). I embraced this idea. It gave me wings directly to school the morning following the Montreal Massacre. For the first time, I understood the children and I had engaged in curriculum making that was permissible, and increasingly I understood our curriculum making as preferable.

I also read Clandinin and Connelly's (1992) chapter, which stands on Dewey's (1938) ideas about continuity, situation, and experience as education and Schwab's (1969) curriculum commonplaces: teacher, subject matter, student, and milieu. By weaving these ideas together, along with the concept of personal practical knowledge, Clandinin and Connelly shoved hard against the long-standing notion of curriculum as a course of study or a set of documents to follow. They understood teachers and children together were composing a curriculum of lives in relation to subject matter, milieus, and contexts. They (1999) also studied the experiences of teachers, listening as they shared tension-filled stories from the professional knowledge landscapes. They coined the term "stories to live by," a narrative concept of teachers' identities at the nexus of "narrative understandings of knowledge and contexts" (p. 4).

These ideas reverberated with teachers and were taken up by researchers. From their 2011 study, Huber et al. understood curriculum making is not limited to schools; curriculum making also occurs in homes and communities. The authors went back to Schwab's curriculum commonplaces (1969) and 
Lugones' (1987) idea of metaphorical worlds and one's capacity to travel between them. They argued not only were teachers moving between home and school whilst engaged in curriculum making, but also that children were similarly engaged. In hindsight, I too was attempting to understand curriculum through this lens as I rode my bike home that December morning; however, I lacked schema and knowledge. Today, this understanding of curriculum allows me to appreciate my lingering story as having the potential to create new stories where communities can allow for the well-being of all and where we can "learn both to engage our differences, celebrating them when we can and also rigorously confronting tensions as they arise" (hooks, 2003, p. 109). Knowing the world this way I experience relief and a relational joining up with the children and the Montreal mothers I had not previously experienced.

\section{Autobiographical Narrative Inquiry and Multiple, Coherent Identities and Communities}

I am an educator. I am a woman. I am a mother. I am a community member and a citizen. I am a creator. These are threads of my identities. I require continuous, moving, beautiful, and flexible stories from each of my identity threads in efforts to compose a meaningful and coherent life. My participation in

D.J. Clandinin's narrative inquiry class allowed me to conceptualize curriculum making as life making such that I experienced narrative coherence (Maclntyre, 1984) between and amongst my threads. Narrative inquiry allowed me to understand the narrative phenomenon of experience and methodology. I was able to inquire into my life making and the life making of students through the lens of a narrative inquirer. As I did so, my experiences slowly began to make sense. Connelly and Clandinin's (2006) notion that, "people shape their daily lives by stories of who they and others are and as they interpret their pasts in terms of these stories" (p. 375), is how I understand what unfolded in our shared classroom the morning after the massacre.

Because I am an educator, parent, and citizen, I am regularly sharing experiences and composing stories, with students, my daughters, and friends. Because I am a narrative inquirer, I understand stories shape who I am and who I might become. And because I was educated to be a narrative inquirer, I regularly find myself holding a three-dimensional narrative inquiry space in my mind (and sometimes I stretch my arms outward and my hands form a triangle) as I inquire into stories. Clandinin and Connelly (2000) described a metaphorical inquiry space as having three sides: temporality ${ }^{8}$ on one side, personal and social $^{9}$ on a second side, and place $^{10}$ on the last side. They also argued that this space consists of four directions of inquiry: inward, outward, backward, and forward. They posited to do research into experience "is to experience it simultaneously in these four directions and to ask questions pointing each way" (p. 50). With narrative inquiry as my methodology, my goal is to understand the interconnectedness between stories composed on one landscape and brought to inform stories that are lived out on another.

She told me. I was excited at the prospect of my youngest child coming to visit and help me move. She was going to be with me for six full days. Some of the time would be taken up with the move; however, I planned daily trips to share my favorite beaches and hiking trails. One particular day I went 
to work in the morning and she packed boxes. Knowing she was coming to pick me up at 2:00, I was highly focused. When the truck rolled up, I jumped in.

We drove out to the Light House, one of my favorite trails. The sun was warm-we had appropriate gear and we were together. We walked along, laughing, occasionally holding hands, sharing stories, and taking pictures. When we came to a wooden bench, my daughter climbed on top and began doing yoga poses. I looked at her; I looked out to the sea and felt its rhythms pass between and through us. I felt mist on my face and arms and the breeze in my hair; I was joyful.

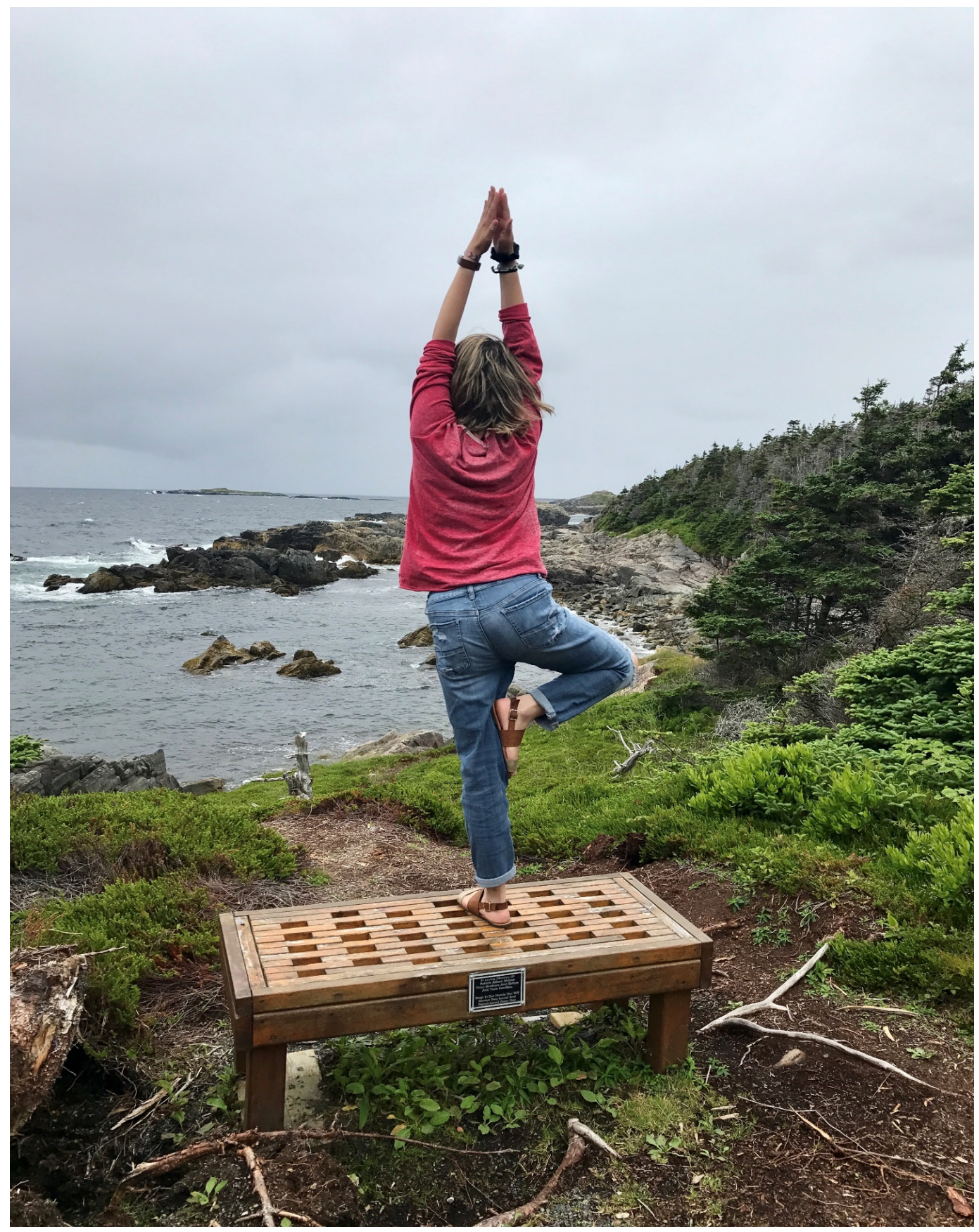

Fig. 1: Daughter doing yoga (Photograph: Jack-Malik, 2017) 
We continued along until we came to a tee in the trail: to the left, we would return to the parking lot; to the right we would be on a more rigorous, less-cared-for trail. My daughter went right and I followed. We went down to the beach, where it was noisier because of the waves. The path was narrow and we therefore walked single file. When she reached the beach, she found a gigantic, flat rock and sat down. Looking back and with her hand, she invited me to join her and I did. She was quiet for a long time. Finally, she looked at me, tears trickling down her beautiful and now twisted face and said,

"Mom, I have to tell you something."

"Okay, my girl, what is it?"

More time passes and she is now breathing erratically and silent tears slide in to sobs.

"What is it? Tell me."

"I can't."

"Are you sick?"

"No"

"Are you pregnant?"

"God Mom! No!"

"Did something happen with Tim (boyfriend)?"

"No."

"Okay, I am going to stop asking. You tell me when you are ready."

We sat on that big, flat rock for a very long time. I listened, as her sobs became occasional gasps for breath and finally normal breathing resumed. I reached my hand across the space between us and rested it on her leg.

"My girl, there is nothing you can tell me that will result in me not loving you."

Then it came, like hot lava taking everything in its path.

"I'm so sorry Mom, I didn't mean for it to happen. Things at work were insane! Every shift they pressured me to sell, even when it was not in the best interest of the client and even when I made quota. When I tried to sleep all I saw was Lucy and her unborn child, both murdered. I did not go to class. I did not get my assignments done. I failed two courses. I'm so sorry Mom. I'm sorry I didn't tell you earlier. I know I should have."

My daughter is crying quietly and staring out at the ocean.

I reached my arm around her and pulled her close.

"My girl, I don't care about school, about passing or failing, I care about you."

"Any mark is good enough, as long as it's above $80 \%$." my daughter gags as she spits this sentence into the space between us.

"What?"

"Do you have any idea how many times you said this to me? Every project, report card, parent teacher interview, it was always the same sentence. When my mark was less than $80 \%$ I felt like I failed you. I wanted you to be proud of me. Do you know how many times I threw work in the garbage so you would not see it? I could not take it Mom. And the money, I know you are mad about the tuition." "I don't care about the money, I care about you and I am very sorry you held on to this story for such a long time. It must have been very hard."

She was quiet and then began to cry and she continued to cry for a very long time. When she stopped, we made our way back to the truck in silence. I held her hand whenever the path was wide enough to allow for it. I held her hand on the drive home. (Excerpt from journal, Jack-Malik, July 2017)

This is life curriculum making, where stories from home, community, and school collide. I regularly spoke to my daughter on the phone and FaceTime. I knew about the murder of her friend and unborn child. Despite these shared conversations, she kept many stories to herself or told me cover stories (Crites, 1979). When I inquire into this story, using the three-dimensional space, I hear my teacher voice, 
through the years, over and over telling her "any mark is acceptable, as long as it is above $80 \%$ " and I know these words shaped the story my daughter shared with me on the beach. I am flooded with memories of assignments and report cards and my absolute frustration with comments and marks that reflected anything but stellar efforts and results. I remember the grounding, the supervised homework, and mostly I remember the face of a child who wanted to be anywhere else. In this moment, the intersection of home and school curriculum making is painful. I feel pangs of guilt and deep concern for my child.

My reaction is acute discomfort as I attempt to sit in the tension. I want to avoid it altogether. I think about calling her and attempting to smooth it over. Through the years, I learned very well how "... to erase, write over and silence ... felt emotions to maintain smooth stories" (Clandinin et al., 2010, p. 82). Instead, I engage in what the authors referred to as self-facing and try to understand how this tension can be "a way of creating a between space, a space which can exist in educative ways" (p. 82).

\section{Struggling to Think and Live Like a Narrative Inquirer}

After my daughter left we continued to talk about the failed courses and the anxiety she experienced before telling me. I listened attentively because I understood the $80 \%$ or else story was temporal in that it continued to shape the stories we were telling and living. I understood it would not be easy for us to tell this story with new insights. I believed the onus was on me if my daughter and I were going to live out new educative stories (Dewey, 1938). I also knew it would have been familiar for me to blame my daughter, accuse her of exaggerating, of being irresponsible and demand she repay the tuition. I also could have ignored my daughter's temporal shifting to stories from our shared early, familial landscapes. I did not because I understand telling the blaming or ignoring story would "distort the moral contours, provide faulty explanations for how the situation came about, feature the wrong collateral events and circumstances while papering over the relevant ones, and depict ways of moving forward that would be morally disastrous" (Lindemann, 2014a, p. 28). Like Dewey's (1938) notion of continuity, I understand that lived stories are carried forward and shape future stories. I wanted to ensure we told this story so that together we could compose educative forward-looking stories. I wanted to take an active role, to be an agent, to retell and relive the stories so we could change.

Then someone else's child. Then a student came to my office and shared stories, including his anxiety. I listened, I stayed in the moment, and I held relational space so that he could be what he needed. He told stories of parental dysfunction grounded in alcohol and drug abuse. He worried constantly that his parents were never going to be and remain sober and that his brothers would end up in care. He said he regularly moved them between his aunts so that children's services would not pick them up. He wanted them to be together. Lindemann (2014b) noted, "serious illness puts pressure not only on individual family members but also on the family itself" (p. 97). He described returning home to find his brothers had not eaten in two days. He raged about teachers who did nothing. In the midst of his rage, I heard my daughter's voice, and world travelled (Lugones, 1987) to our relational space on the beach. I felt warmth and mist on my skin and I knew I could be in the room with this young man. He finally exhausted himself and turned his attention to his outstanding assignments. I suggested we think 
about how he could carve out time to complete them. I told him I cared about him and his brothers. I gave him my phone number, something I have never done. I also told him I had some appreciation of how hard his life was because recently I had begun to understand the far-reaching effects of anxiety.

I was able to speak with this young man because of the story my daughter and I experienced on the beach and because I did the hard work of self-facing stories. Leaning heavily on and trusting Clandinin et al.'s (2010) idea of tension as an educative space between, I knew the importance of holding relational silence in the midst of acute tension to allow the other to speak, regardless of how long it took. Van Der Kolk's (2014) work also informs me. He wrote,

social support is not the same as merely being in the presence of others. The critical issue is reciprocity: being truly heard and seen by the people around us, feeling that we are held in someone else's mind and heart. (p. 81)

Fully engaging the inquiry. Part of narrative inquiry involves sharing the account to ensure it cleaves to the story as the other intended. As well, an important part of narrative inquiry is concern for relationships. I needed to remind my daughter that when the work was shared and published, she would be implicated. I wanted to give her multiple opportunities to respond to what I had written and I wanted to acknowledge what she was feeling. I understood I would continue to live in relationship with my daughter, after this research was completed; therefore, my focus was on the relational. I also wanted to remind her that she could say no, and therefore I would remove her story. I was thinking about this when my phone rang. It was my daughter on Facetime. She said the call was unintended and perhaps the weight of the dog's paw activated the phone. We laughed. I told her I wanted to chat and asked if she had time. She said yes. I told her I was calling to share a narrative account of our experiences because I wanted it to represent what she remembered and I wanted her to respond to how she was represented in the text. I was nervous. I began reading slowly, purposefully. It did not take long before we were both crying and wiping away tears. When I finished I asked what she thought. I also put the pages down and looked at her. This is what she said:

Before now when I thought about my visit to you, everything was great except I felt really bad about what happened on the beach. I felt liked I dumped on you and made you responsible for me failing the courses, for not telling you and for wasting your money. Now when you read this to me, I hear you say something else, something important. I know I was the one who failed and I do want you to be proud of me. I also know it is hard to talk about these things. The part you wrote about wanting to get the story down so we could change and that you didn't want to blame me that means a lot to me mom. Some days are so hard. School is so hard and many professors are dicks who don't want to hear about accommodations. On the beach that day mom, I knew you heard me and I felt safe and loved. I knew I screwed up and I knew you cared more about me than the screw up. (Facetime research conversation, January 2018)

We agreed we would talk the following week after we both had time to think about the text.

Once again, I reminded her she could tell me to remove her story. This time we went through the text, line by line. She made word choice suggestions and she asked that I remove sentences; I made all changes. We co-constructed the text in efforts to describe our relational experiences. I shared the entire article because I wanted her to understand what I had learned. 
Van Der Kolk's (2014) work helps to deepen my understandings of what my child shared. He wrote, "being able to feel safe with other people is probably the single most important aspect of mental health; safe connections are fundamental to meaningful and satisfying lives" (p. 81).

Tension is an opportunity. The story from the morning following the massacre lingered with me for many years. The story I shared with my daughter also lingers. The story of the young man who came to my office joins these stories. Each story includes tensions when curriculum making on one of the landscapes (home, school, and community) collides. In the first story, I had no way of extrapolating knowledge because I was not a narrative inquirer and because I was living at a time when there was no consideration of curriculum making occurring at home, school, and in the community. Nevertheless, I had the experience of three small girls reaching through the tension and silently comforting me. I have always felt deep gratitude for the children. When they embraced me, I felt soothed. It would be years before I had the language and knowledge to name it as curriculum making and as a story that informed future curriculum making stories in educative ways. Once I knew it this way, I wanted to live stories where I did for others what the little girls did for, and with, me. Sitting on the beach with my daughter, I was the three little girls. Sitting in my office with the young man, when the temporality of my early stories was screaming at me to exit, I was able to stay in the tension, within the relational space. The three little girls, my daughter, and the young man are teaching me to be still, to hold, to wait, to listen, to be present in silence. These stories are teaching me there are no divides between the curriculum-making landscapes; there is however, fluidity. They also remind me to think hard before framing tension as something to be avoided. Finally, these stories teach me the importance of taking time to inquire. It is a wonderful goal to set to be a curriculum maker who lives relationally and allows past experiences to inform future ones. For me this means, slowing down, choosing carefully, and thinking deeply. When I do these things, I know curriculum making, as sentient, ever changing and as support as one struggles to shift identities.

Autobiographical narrative inquiry is like setting a camera's aperture to the $\mathrm{f} / 1.4$ stop. It encourages a wide berth as to what counts as useful research for teachers and it makes a space for many, divergent voices, including teacher voices. I understand this as a good thing because classrooms are regularly sites of complex tension and places where teachers meet and come into moments of tension with students who do not share similar experiences. In writing about my own experiences, it was partly my intention to make sense of my tension-filled stories and write a meaningful account of them. In turn, I hoped these accounts would sensitize readers to the tension experienced by teachers and students as they move amongst the various curriculum-making landscapes. Most importantly, it is my hope that this work offers the reader a moment to suspend what can be iron-clad knowing and enter into worlds of empathy with those who we experience as different.

Autobiographical reflection allows teachers to deepen their understandings of who they are and how their knowing shapes how they interact with students, families, and colleagues. When a teacher stops to reflect on what she is doing and who the students are in her class, she has an opportunity to create new stories. The reflection and inquiry often opens spaces for ambiguity and wonder. Inside the spaces a teacher can safely imagine the life of a student with empathy and compassion. Moreover, if we name the experiences students and teachers are having at school, home, and in the community as curriculum 
making, then we provide a scaffold from which to reflect on and analyze a teacher's practice as she travels between landscapes. Furthermore, naming curriculum making this way would interrupt the privileging of school curriculum making. When we inquire and reflect we have the opportunity to deepen our understandings of how to negotiate tension in educative ways because we better understand why we make certain decisions. As well, it provides an opportunity to explore stories from our earliest landscapes, which can be influencing decision making in ways one does not appreciate. A teacher then has an option to begin living out new stories, which are a better fit for her new understandings.

Finally, this work is important because it illustrates a facet of teaching that is under egregious attack as we march along a path of standardized education and accountability to test scores. Content and pedagogy must be rooted in a solid foundation of respectful, caring, and, I would argue, loving relationships between students and teachers. Loving my daughter, being mindful of our relationship, allowed us to experience tension and then together find a way forward. Tension happens at school, every day and in every classroom-autobiographical reflection offers teachers a way to make sense of tension in meaningful ways and to live out new stories grounded in new understandings of who they are and who they want to become.

\section{Notes}

1. Connelly and Clandinin (2006) used four terms to "structure the process of self-narration." Lived stories are those we live. Told stories are those we tell. Retold stories are those used "to interpret lives as told in different ways, to imagine different possibilities" (p. 478). To relive stories is "to live out the new possibilities" (p. 478).

2. Priority school is a term used to describe a school where students require additional support if they are to meet provincial achievement goals.

3. Montreal Massacre: The École Polytechnique massacre, also known as the Montreal massacre, was a mass shooting at that occurred on December 6, 1989. It is the deadliest mass shooting in Canadian history.

4. Pseudonyms are used to protect the children's identities.

5. This story is taken from my doctoral dissertation (Jack-Malik, 2012).

6. Clandinin and Connelly (1995) shared the idea of professional knowledge landscape to allow us to think about schools as landscapes of "space, place, and time" (p. 4). These landscapes they posited are "filled with diverse people, things, and events in different relationships" (p. 4).

7. Bloom's Taxonomy (1956): Consisted of six major categories: Knowledge, Comprehension, Application, Analysis, Synthesis, and Evaluation. The categories after Knowledge were presented as "skills and abilities," with the understanding that knowledge was the necessary precondition for putting these skills and abilities into practice.

8. Temporality: Clandinin and Connelly, 2006) noted, "...events under study are in temporal transition" (p. 479). By this they mean all events and people have a past, present, and a future, and it important to appreciate they are in a process and changing.

9. Sociality: Connelly and Clandinin (2006) argued narrative inquirers must simultaneously attend to personal conditions, "feelings, hopes, desires, aesthetic reactions and moral dispositions" (p. 480).

10. Place: Connelly and Clandinin (2006) described "the specific concrete, physical, topological boundaries of place or sequence of places where the inquiry and events occur" (p. 480). 


\section{References}

Clandinin, D.J. (1986). Classroom practice: Teaching images in action. Philadelphia, PA: Falmer.

Clandinin, D.J., \& Connelly, F.M. (1992). Teaching as curriculum maker. In P.W. Jackdaughter (Ed.), Handbook of research on curriculum (pp. 363-401). New York, NY: Macmillan.

Clandinin, D.J., \& Connelly, F.M. (1995). Teachers' professional knowledge landscapes. New York, NY: Teachers College Press.

Clandinin, D.J., \& Connelly, F.M. (1999). Stories to live by: Narrative understandings of school reform. Curriculum Inquiry, 28(2), 149-164.

Clandinin, D. J., \& Connelly, F. M. (2000). Narrative inquiry: Experience and story in qualitative research. San Francisco, CA: Jossey Bass.

Clandinin, D.J., Murphy, M. S., Huber, J., \& Orr, A.M. (2010). Negotiating narrative inquiries: Living in a tension-filled midst. International Journal of Educational Research. 103. doi:10.1080/00220670903323404.

Crites, S. (1979). The aesthetics of self-deception. Soundings, 62, 107-129.

Connelly, F.M., \& Clandinin, D.J. (1988). Teachers as curriculum planners: Narrative of experience. New York, NY: Teachers College Press.

Connelly, F. M., \& Clandinin, D. J. (2006). Narrative inquiry. In J. L. Green, G. Camilli, \& P. Elmore (Eds.), Handbook of complementary methods in education research (3rd ed., pp. 477-487). Lawrence Erbaum Associates, Inc.

Dewey, J. (1938). Experience and education. New York, NY: Collier.

hooks, b. (2003). Teaching community: A pedagogy of hope. New York, NY: Routledge.

Huber, J., Murphy, M. S., \& Clandinin, D. J. (2011). Places of curriculum making: Narrative inquiries into children's lives in motion. Bingley, UK: Emerald Publishing.

Jack-Malik, S.M.D. (2012). Literacies and three women's on-going stories to shift identities: A narrative inquiry. Unpublished doctoral dissertation, University of Alberta, Edmonton, Canada.

Jack-Malik, S.M.D. (2017). Daughter doing yoga. Cape Breton Island, Nova Scotia.

Lindemann, H. (2014a). When stories go wrong. Hasting Center Report. Retrieved from http://dx.doi.org/10.1002/hast.266.

Lindemann, H. (2014b). Why family matter. Pediatrics. doi:10.1542/peds.2014-1394E

Lugones, M. (1987). Playfulness, "world"-travelling and loving perception. Hypatia, 2(2), 3-37.

MacIntyre, A. (1984). After virtue: A study in moral theory (2nd ed.). Notre Dame, IN: Notre Dame University Press.

McIntosh, P. (1989). White privilege: Unpacking the invisible knapsack. Peace and Freedom, July/Aug. Retrieved from https://psychology.umbc.edu/files/2016/10/White-Privilege_McIntosh-1989.pdf. 
Schwab, J.J. (1969). The practical: A language for curriculum. The School Review, 78(1), 1-23.

Van Der Kolk (2014). The body keeps the score: Brain, mind, and body in the healing of trauma. New York, NY: Viking.

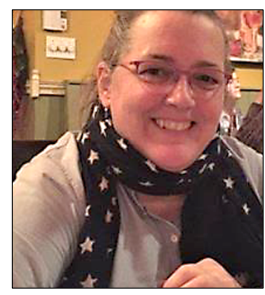

Sandra Jack-Malik, PhD, is an Assistant Professor in the Department of Education at Cape Breton University in Nova Scotia. She teaches curriculum and instruction courses in English language arts to elementary and secondary preservice teachers. A qualitative researcher, her primary interests lie at the intersections of literacies and identities and the pedagogies that support students to close achievement gaps. She is also interested in the experiences of preservice and in-service teachers as they work to support struggling students and the implications these understandings can have on teacher education programs. 